Santi Romero

\title{
2 Using Historic Buildings to House New Libraries: Prerequisites and Conditions for Successful Revival
}

\begin{abstract}
This chapter discusses the advantages and disadvantages of the rehabilitation of historic buildings for library use. The architectural characteristics of different types of historic buildings are examined to ascertain which are the most suitable for new use as a library. A work methodology is also proposed to help assess the suitability of housing new libraries in historic buildings, diagnosing the conservation status and precisely determining the actions to be followed. Finally, the factors that should come together before accepting the proposal to create a library in a historic building are listed. Examples provided are taken from projects in Spain.
\end{abstract}

Keywords: Library buildings; Buildings - Protection; Buildings - Remodelling for other use; Public libraries - Spain

\section{Introduction}

Many countries have important architectural heritages and libraries often provide an ideal opportunity for the reuse of heritage buildings no longer serving their original purposes. Many people like the idea, but others are alarmed and negative to the prospect of reuse of old buildings. Rigour is required when analysing the pros and cons of reuse library projects.

\section{Advantages and Disadvantages of Building Renovation}

Renovation of heritage sites has obvious advantages but is surrounded by technical, functional, financial and sometimes aesthetic pitfalls. These vary according to the nature of the building and take on more or less importance depending on how the final result is envisaged.

2 Open Access. (2021 Santi Romero, published by De Gruyter. (c) BY-NC-ND This work is licensed under the Creative Commons Attribution-NonCommercial-NoDerivatives 4.0 International License. 


\section{Advantages}

What are the main advantages of converting a historic building into a library?

- The location, given that historic buildings often occupy extremely suitable sites

- The symbolic value of the building in the community. An example is the public library Biblioteca Marta Mata/Marta Mata Library in Cornellà de Llobregat (https://bibliotecavirtual.diba.cat/es/cornella-de-llobregat-bibliotecamarta-mata; https://bibliotecavirtual.diba.cat/documents/347861/0/COR NELLA+DE+LLOBREGAT-+Biblioteca+Marta+Mata-.pdf/e8711c6e-7219-42a2a6b9-3bc27b39268d). It occupies a former iconic movie theatre of significant value to the community, which was expanded to accommodate the library (Figure 1)

- The architectural interest of an historical structure as shown in the public library Biblioteca El Molí/El Molí Library in Molins de Rei, (https://bibliotecavirtual.diba.cat/en/molins-de-rei-biblioteca-el-moli; https://bibliotecavirtual.diba.cat/documents/348654/0/Molins+de+Rei+-+El+Mol\%C3\%AD/ e349ea70-1cfb-4472-89e8-9b8ec50f9c59) which exploited the features of one part of the ground and two upper levels of a former textile factory which was of considerable architectural significance (Figure 2)

- The preservation of the building, which otherwise will inevitably deteriorate if left in disuse.

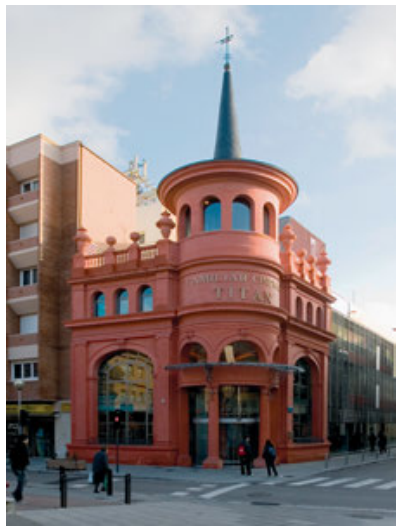

Fig. 1: Biblioteca Marta Mata/ Marta Mata Library, Cornellà de Llobregat. Architect: Antonio Montes. (C) Oscar Ferrer, ago2.



Fig. 2: Biblioteca El Molí/El Molí Library, Molins de Rei. Architect: Antonio Montes. (C) Imma Sabater. 


\section{Disadvantages}

What might be the main obstacles to overcome?

- The typology of the building, which could have:

- An extremely rigid and fragmented distribution of spaces

- Floor level changes that make it difficult to meet regulatory requirements on architectural barriers

- Façades with few windows that restrict the interior-exterior visual relationship so vital to a library

- An entire structure needing reinforcement to bear the weight of the bookshelves

- Problems adding lifts and staircases that meet accessibility, fire or other regulations

- The level of heritage protection afforded to the building, which can sometimes lead to retention of features which are impediments to achieving a functional library

- The complexity of the works, given that it is generally more difficult to rehabilitate an old building than build a new one

- Almost always, the cost of the works.

\section{Typological Considerations of Converting Buildings}

The typology of a historic building can make it more or less difficult to insert a library. Examples of reuse of various types of buildings are provided in the following.

\section{Manor Houses}

Single-family manor houses tend to be problematic as they generally have small surface areas with spaces fragmented and distributed on several levels. As a result, they may be suitable for specialist libraries with small numbers of visitors. The Biblioteca El Castell/El Castell Library in Vacarisses provides an example of such use (https://bibliotecavirtual.diba.cat/es/vacarisses-biblioteca-el-castell; https://bibliotecavirtual.diba.cat/documents/351824/0/Pl\%C3\%A0nols +i+fotos+ de+la+biblioteca+El+Castell/3e62c49d-8830-456d-beda-be69a742a798) The public library occupies a former manor house built on the ruins of an old castle. It was 
necessary to add a new extension to accommodate the entire library programme (Figures 3 and 4).

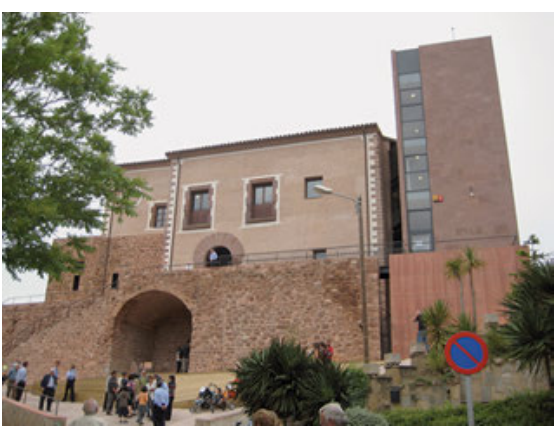

Fig. 3: Biblioteca El Castell/El Castell Library, Vacarisses. Architect: Xavier Guitart Tarrés, GAA SLP. @ Santi Romero.

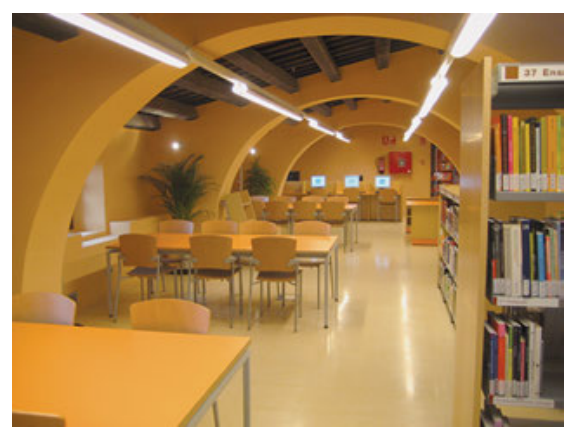

Fig. 4: Biblioteca El Castell/El Castell Library, Vacarisses. Architect: Xavier Guitart Tarrés, GAA SLP. ( ) Santi Romero.

\section{Palaces and Castles}

Palaces and castles provide opportunities for transformation into effective contemporary libraries, with large interior spaces to ensure flexibility. They tend to be in the city centre or in areas linked to parks and can be good locations for certain types of libraries. The public library Biblioteca La Cooperativa/ La Cooperativa Library in Malgrat de Mar (https://bibliotecavirtual.diba.cat/es/ malgrat-de-mar-biblioteca-la-cooperativa; https://bibliotecavirtual.diba.cat/ documents/348283/0/MALGRAT+DE+MAR-Biblioteca+La+Cooperativa.pdf/ ef4739c3-1f80-4ab4-b6d2-c34a832fd9a5) is a good example of a rehabilitation project, since it was possible to clear a large part of the previous structure, raise the roof without its being visible from outside the building, and put in a large picture window in the rear façade (Figures 5, 6 and 7). 

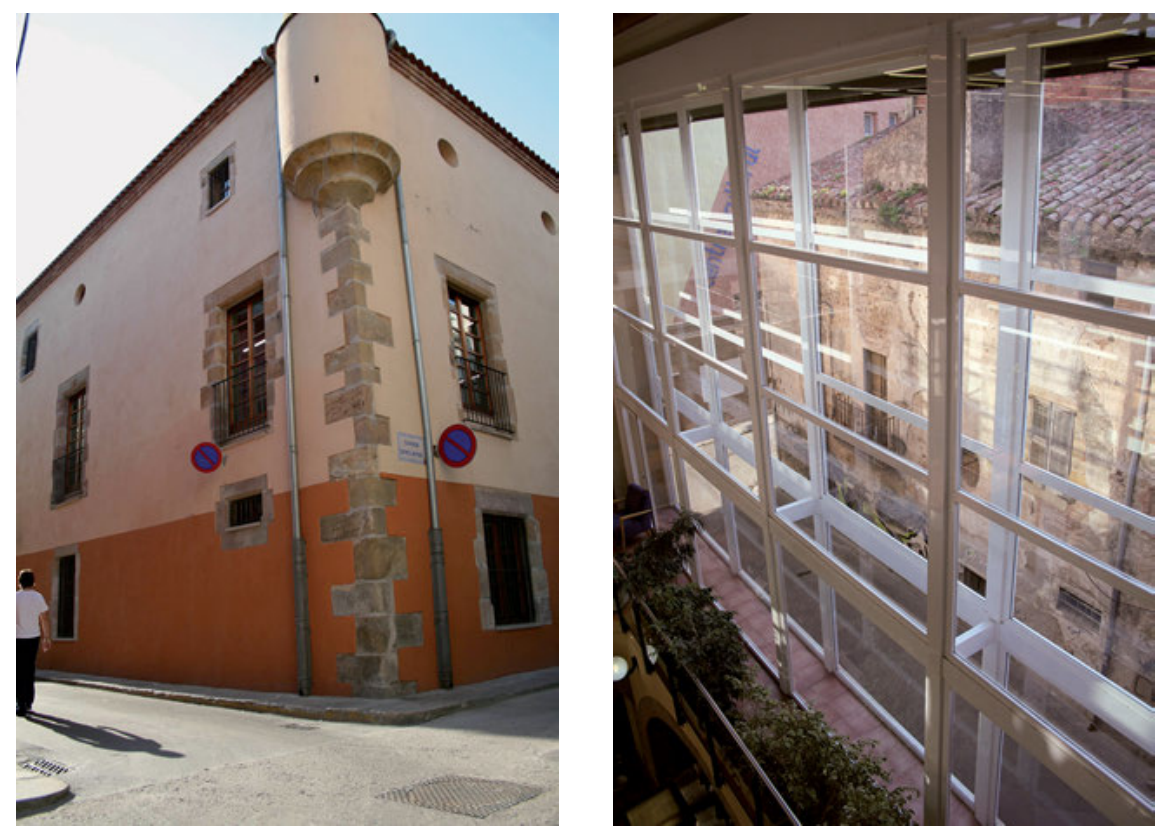

Figs. 5 and 6: Biblioteca La Cooperativa/La Cooperativa Library, Malgrat de Mar. Architect: Josep Maㅡomaní. (c) Montse Martínez.

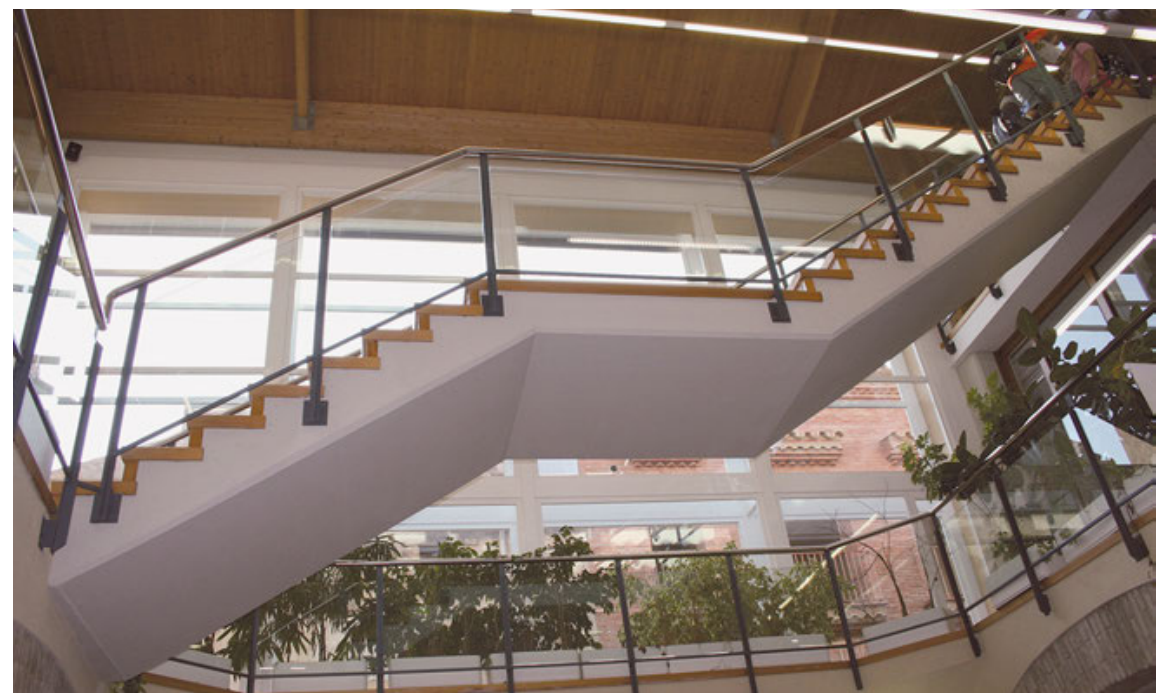

Fig. 7: Biblioteca La Cooperativa/La Cooperativa Library, Malgrat de Mar. Architect: Josep Mํㅗ Romaní. (c) Montse Martínez. 


\section{School Buildings, Hospitals and Convents}

Buildings formerly functioning as schools, hospitals and convents are adaptable because they tend to be large and composed of spaces with diverse characteristics. They can be comparatively easily modified to suit the purposes of a library. The Biblioteca Sant Pau-Santa Creu/Sant Pau-Santa Creu Library in Barcelona (https:// bibliotecavirtual.diba.cat/es/barcelona-ciutat-vella-biblioteca-sant-pau-isanta-creu; https://bibliotecavirtual.diba.cat/documents/347084/0/BARCELONA +CIUTAT+VELLA-Biblioteca+Sant+Pau+i+Santa+Creu.pdf/95970a7d-e433-4620b6de-40ddd51e870b) occupies part of the former Hospital de la Santa Creu, one of the oldest hospitals in the world, which ceased to serve as a hospital in the early $20^{\text {th }}$ century. The facilities were reorganised and refurbished in 2010 to feature the building's splendid origins and today form a single public library with different sections to cater for all users (Figure 8).

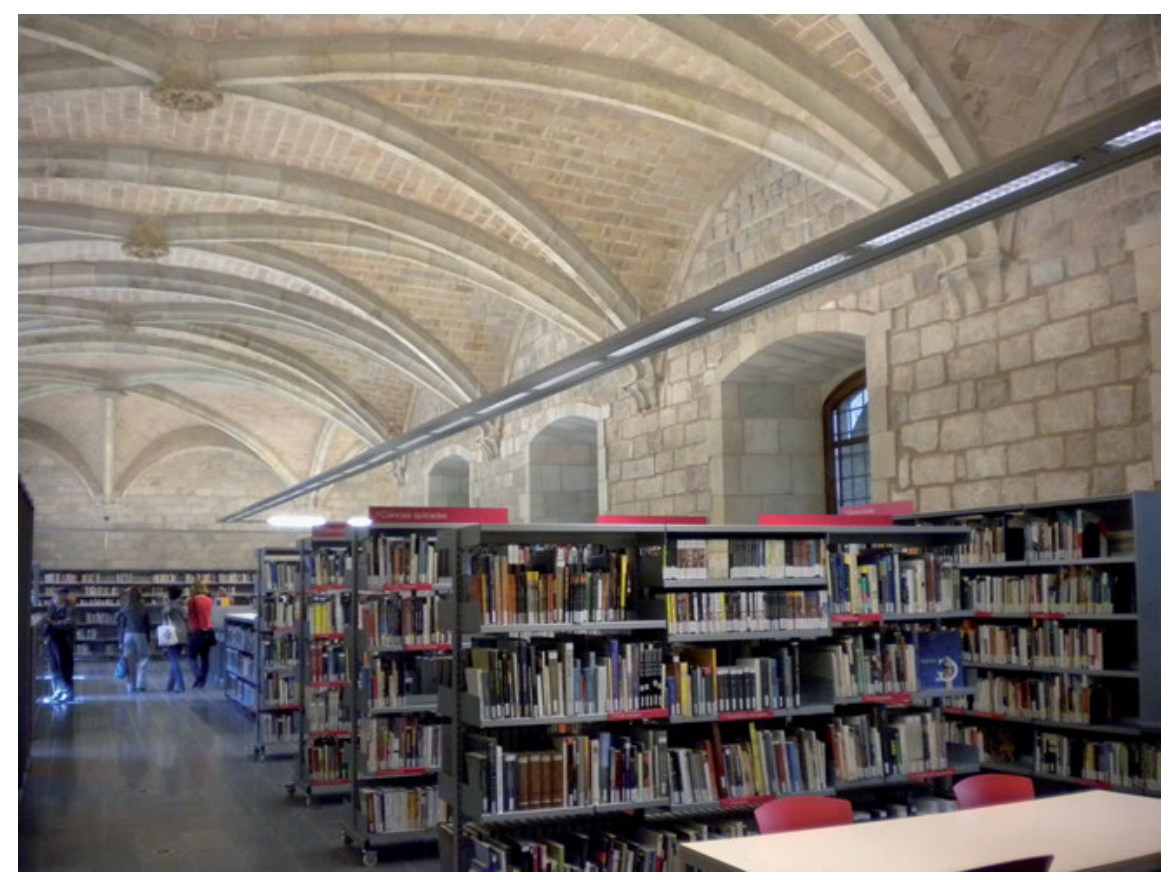

Fig. 8: Biblioteca Sant Pau-Santa Creu/Sant Pau-Santa Creu Library, Barcelona. Architect: ARQ FORUM S. L. (c) Ignasi Bonet.

Convents sometimes have courtyards or cloisters and the façades tend to have regular openings that provide good natural light which can be optimised in pro- 
jects reusing the buildings for libraries. The public library Biblioteca Joan Triadú/ Joan Triadú Library in Vic (https://bibliotecavirtual.diba.cat/es/vic-bibliote ca-joan-triadu; https://bibliotecavirtual.diba.cat/documents/351872/0/VIC-Bib lioteca+Joan+Triad\%C3\%BA.pdf/8287a430-575d-4f0b-adc0-f164813898e1) occupies the cloister and one half of the former Convent del Carme, capitalizing on the light available, with the remainder of the building occupied by a museum (Figures 9 and 10).



Fig. 9: Biblioteca Joan Triadú/ Joan Triadú Library, Vic. Architects: Bosch-Cuspinera Associats. (C) Oscar Ferrer, ago2.

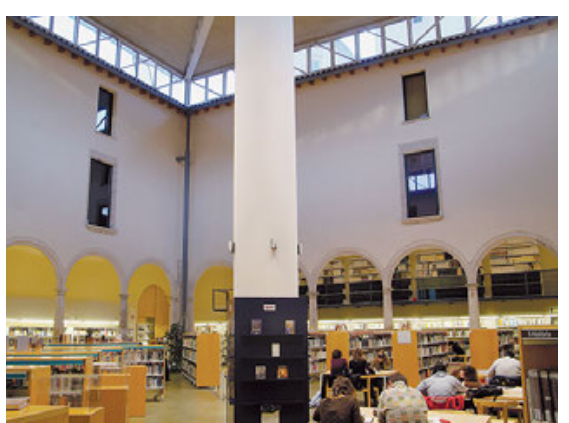

Fig. 10: Biblioteca Joan Triadú/ Joan Triadú Library, Vic. Architects: Bosch-Cuspinera Associats. (c) Oscar Ferrer, ago2.

In buildings formerly operating as schools and hospitals, layouts using a central corridor with classrooms or dormitories on either side mean that large spaces can be liberated for alternative use. Conversely, a layout with a lateral corridor which is separated from the rooms by load-bearing walls offers only continuous spaces which are difficult to convert.

The public library Biblioteca Nou Barris/Nou Barris Library in Barcelona (https://bibliotecavirtual.diba.cat/es/barcelona-nou-barris-biblioteca-nou-bar ris; https://bibliotecavirtual.diba.cat/documents/346997/0/Pl\%C3\%A0nols+i+ fotos+de+la+biblioteca+Nou+Barris/888d7f24-611a-4843-afff-134afb144b87) occupies part of the former Institut Mental de la Santa Creu/Santa Creu Mental Institute. In the refurbishment, it was possible to locate the staircase and the lift at the intersection of two areas at right angles to each other (Figure 11). Redistribution of spaces for parts of the Library were facilitated (Figure 12). 




Fig. 11: Biblioteca Nou Barris/Nou Barris Library, Barcelona. Architects: Ricard Pèrdigo and Tomàs Rodríguez. (C) Santi Romero.

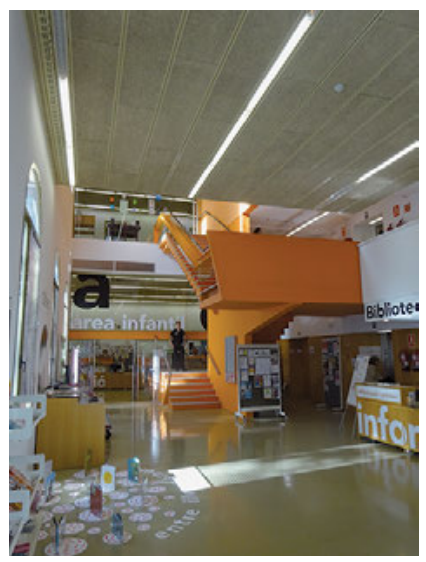

Fig. 12: Biblioteca Nou Barris/Nou Barris Library, Barcelona. Architects: Ricard Pèrdigo and Tomàs Rodríguez. (C) Santi Romero.

\section{Industrial Buildings}

Industrial buildings are perhaps the most suitable for recycling as libraries, having initially been designed to be used by large numbers of people simultaneously. The structural system tends to be highly resistant to overloading and is distributed using pillars, which allows for flexibility.

Factories or warehouses generally have large, single-level spaces and the façadesarelikely to havelargeopenings that let in natural light. Thesefeatures have been used to good effect in the public library Biblioteca Can Manyer/Can Manyer Library which occupies one of the buildings of a former textile factory (https:// bibliotecavirtual.diba.cat/es/vilassar-de-dalt-biblioteca-can-manyer; https://bib liotecavirtual.diba.cat/documents/29951453/0/VILASSAR+DE+DALT+-+Biblio teca+Can+Manyer.pdf/d8ae7185-1fc9-47f2-8bd1-3fb56fbcf802) in Vilassar de Dalt (Figure 13). In 2018, the public library Biblioteca Montserrat Abelló/Montserrat Abelló Library in Barcelona (https://bibliotecavirtual.diba.cat/es/barcelonales-corts-biblioteca-montserrat-abello; https://bibliotecavirtual.diba.cat/docu ments/346767/0/BARCELONA+LES+CORTS-+Biblioteca+Montserrat+Abell $\% \mathrm{C} 3 \% \mathrm{~B} 3+\mathrm{i}+$ Soler+.pdf/fae73678-c46f-4278-95ab-32b839efa6f2) opened in the former Benet i Campabadal factory. The factory was originally built in 1924 for the production of silk ribbon and in 1990 converted to a facility combining glassmak- 
ing, industry and art. The library's design and impact result from the way natural light is used with open façades and skylights (Figure 14).

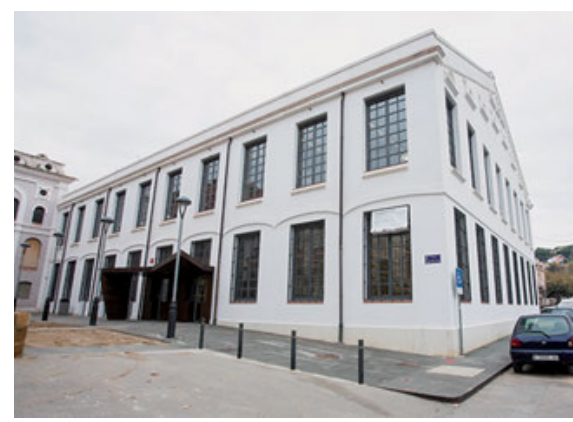

Fig. 13: Biblioteca Can Manyer/Can Manyer Library, Vilassar de Dalt. Architects: Xavier Fabré and Lluís Dilme. (c) Oscar Ferrer, ago2.

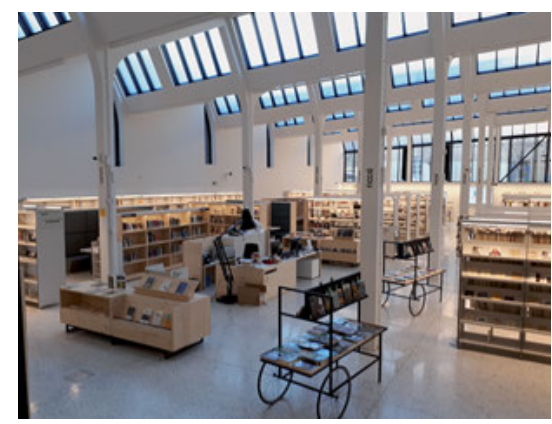

Fig. 14: Biblioteca Montserrat Abelló/ Montserrat Abelló Library, Barcelona. Architects: Ricard Mercadé and Aurora Fernández. (c) Mercè Millan.

The Biblioteca Central Tecla Sala/Tecla Sala Central Library in L'Hospitalet de Llobregat (https://bibliotecavirtual.diba.cat/es/hospitalet-de-llobregat-l-bibliote ca-tecla-sala; https://bibliotecavirtual.diba.cat/documents/348151/0/L\%C2\%B4 HOSPITALET+DE+LLOBREGAT-Biblioteca+Tecla+Sala.pdf/72872342-9be8449a-aac7-c09ff3cf1199) occupies a former textile factory that was renovated to house a cultural centre comprising a public library and a museum of identical dimensions. Since both organisations wanted the best location inside the building, the architect opted for a Solomonesque solution, coming up with the idea of an exterior ramp to locate the entrance adjacent to both facilities in the geometric centre of the building. From there, the museum occupies half of the first floor and all the ground floor, while the library occupies the other half of the first floor and all the second floor (Figures 15 and 16). 


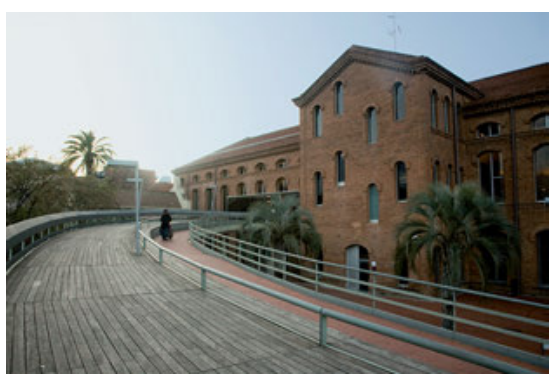

Fig. 15: Biblioteca Central Tecla Sala/Tecla Sala Central Library, L'Hospitalet de LLobregat. Architect: Albert Viaplana. (C) Oscar Ferrer, ago2.

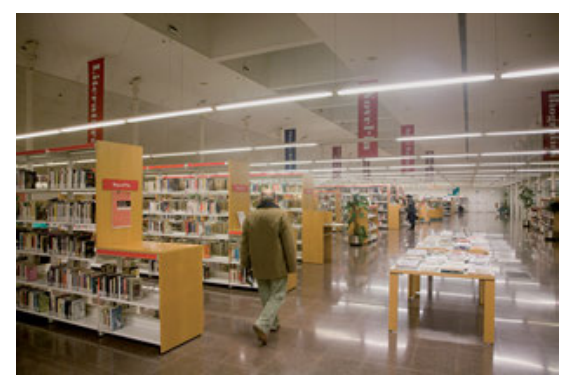

Fig. 16: Biblioteca Central Tecla Sala/ Tecla Sala Central Library, L'Hospitalet de LLobregat. Architect: Albert Viaplana. (C) Oscar Ferrer, ago2.

\section{Churches}

Churches offer opportunities for transformation into libraries. They tend to be centrally situated in urban areas and have large spaces with no internal subdivisions. The disadvantage is that they are closed to the external environment and have little natural light to the interior. The large volume of internal space makes such structures difficult to heat or cool. The Centro de Documentación de las Artes Escénicas de Andalucía/ Andalucia Performing Arts Documentation Centre (https://divisare.com/projects/300122-ssw-arquitectos-fernando-alda-cen tro-de-documentacion-de-las-artes-escenicas-de-andalucia; https://www.junta deandalucia.es/cultura/redportales/cdaea/) in Sevilla, was an adaptation project for the church of Santa Lucia for use as the Andalucía Performing Arts Documentation Centre. The $14^{\text {th }}$ century church with its three naves separated by brick arches made a good home for the documentation centre but providing appropriate air conditioning proved challenging (Figure 17). 




Fig. 17: Centro de Documentación de las Artes Escénicas de Andalucía/ Andalucia Performing Arts Documentation Centre, Sevilla. Architect: Miguel Bretones del Pozo (SSW Arquitectos). (C) Curro Casillas.

\section{Markets}

Markets no longer in use are types of buildings which can be transformed into libraries. They generally have central locations in an urban context and large spaces without internal subdivisions. Their structure meets the flexibility and strength requirements of a library, and ceiling heights allow floors to be added. 


\section{Working Methods}

When the renovation of a heritage building for library use is considered, it is a good idea to analyse all the historic, architectural, technical and financial questions to assess the extent of the operation. The detailed results of the analysis will facilitate the decisions to be made in planning the project. A general overview and concept brief must be prepared and careful financial considerations borne in mind in determining aspects of the project.

The variety of different projects and types of historic buildings being used makes it difficult to generalize about a specific working method. However, any assessment of the overall project should include the following phases:

- Determination of the objectives of the new facility and the outcomes required

- In-depth study of the existing building and its surrounds, identifying any issues

- Diagnostic report.

\section{Determining the Objectives of the New Facility}

The first step would be to devise a quantitative and qualitative functional programme of outcomes, based on the library's needs as defined by examining documentation, surveys and consultation with stakeholders. The requirements for the new facility should be identified without considering that it will be housed in a historic building.

\section{In-depth Study of the Existing Building}

The next phase would be to study the building in detail, paying attention to:

- The general state of preservation of the building

- The most significant defects

- Strength of the walls, foundations and structure

- Historic building legislation identifying the features which must be retained and those which can be modified

- The surface area of the building and dimensions of the principal spaces

- The repercussions of adapting the building to accessibility, fire and other regulations. 


\section{Diagnostic Report}

Finally, a report that includes the following aspects would be produced:

- A comparative study of the library's requirements covering the contents of the functional programme and the adaptation potential of the building

- An assessment of the complexity of the project

- An approximation of costs involved.

\section{Summary and Conclusion}

Leaving political and social interests and pressures aside, the following factors should come together before deciding to install a library in a historic building:

- Satisfactory location as demonstrated with the Biblioteca Joan Triadú/ Joan Triadú Library which occupies the cloister and one half of a religious convent in the historic centre of the city of Vic (Figure 18)

- Building typology suitable for the new purpose as shown with the Biblioteca Can Manyer/Can Manyer Library in a former textile factory (Figure 19)

- Surface area sufficient for the whole programme to operate on a small number of floors

- Favourable diagnosis of the state of the building

- Appropriate budget.

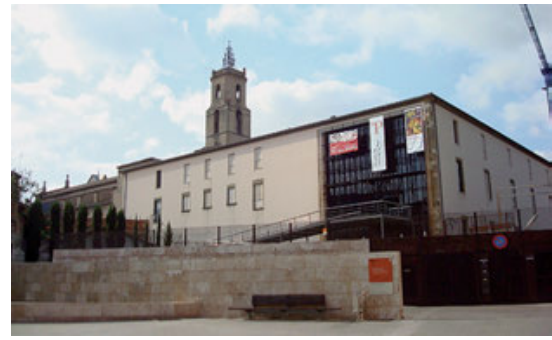

Fig. 18: Biblioteca Joan Triadú/ Joan Triadú Library, Vic. Architects: Bosch-Cuspinera Associats. (c) Oscar Ferrer, ago2.

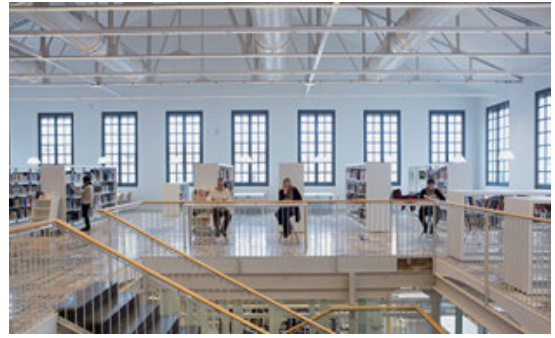

Fig. 19: Biblioteca Can Manyer/Can Manyer Library, Vilassar de Dalt. Architects: Xavier Fabré and Lluís Dilme. (c) Oscar Ferrer, ago2.

And finally, if the project goes ahead, it is important to accept two things:

- The library may not be as functional as it would be in a new building designed specifically for the purpose, because the functional programme may have to 
adapt to the limitations of the existing building, for which the right solution will have to be found.

- The architect must enjoy a certain degree of creative freedom, despite the restrictions imposed by working on a historic building.

Reuse projects are often executed under the public gaze and a vote of confidence must be given to the architect who decides to echo the architectural language of the original building or, alternatively, chooses to mark new interventions by using a $21^{\text {st }}$ century design.

In this chapter, the advantages and disadvantages of the rehabilitation of historic buildings for library use have been described; the architectural characteristics of the different building types analysed; and a work methodology has been proposed to help reach the appropriate decision when faced with specific situations. Further details can be found in Romero's book on library architecture (Romero 2008).

On many occasions the size of the building to be renovated is insufficient to house the library being planned and it is necessary to carry out a renovation and extension project. The difficulty of this type of project is finding the fit between the architectural solution adopted for the historic building and that for the proposed extension. The successful blending of old and new is complex and challenging and how to find successful solutions must be left for another day.

\section{References}

Romero, Santi. 2008. Library Architecture: Recommendations for a Comprehensive Research Project. Barcelona: Col-legi d’Arquitectes de Catalunya. https://www.diba.cat/ documents/16060163/22275360/library_architecture_santi_romero.pdf/0050e693-63d9485d-8b97-623bfdcd9e61 